\title{
Changes of Income Situation Farm Household and its Functions
}

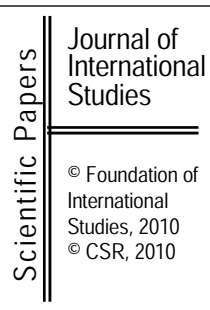

\author{
Dr Barbara Chmielewska \\ Institute of Agricultural and Food Economics - \\ National Research Institute \\ General Economics Department \\ chmielewska@ierigz.waw.pl
}

\begin{abstract}
The functions of agricultural holdings have been identified on the basis of identifying the main sources of income. As a result of the transformation of Polish economy and integration with the EU, the functions of agricultural holdings have to a large extent changed. Households and production holdings are now treated as two separate entities. At the same time polarization of farm households have emerged into agricultural holdings and subsistence farms. The number of holdings with mixed sources of income has also increased. Agricultural holdings and rural areas evolved from single-functional to multi-functional in nature.
\end{abstract} Submitted: March, 2010 $1^{\text {st }}$ revision: May, 2010 Accepted: July, 2010

Keywords: income sources of agricultural holdings, polarization, functions.

JEL classification: D31, J43, P2.

\section{Introduction}

Households and production holdings are now being treated as two separate entities. Technological progress and mechanisation of farming made workforce less necessary in the fields and in the work with animals. Relations between prices became much less favourable for agriculture. In addition, due to fragmented agrarian structure, especially in small holdings, agriculture-based income ceased to be able to provide families with a satisfactory standard of living. A farmer family no longer specialized in one domain only and is now multiprofessional. Similarly, agricultural holdings as well as production holdings started to perform social, recreational, environmental and cultural roles.

This shift stemmed to a large extent from the fact that it was difficult to find employment in any other sector than the agricultural one. Initially, farmers were able to get an additional income by working in the cities but in the late 1980s and early 1990s this market became much less accessible for those who were not in demand in the agricultural sector. Those persons have a low level of education which is frequently not adequate in terms of what employers expect. Another important obstacle for employment proved to be housing problems (absence of inexpensive accommodation in the city) and transportation difficulties (commuting to work). Rural population was forced to "organise" their own workplaces in their place of residence. Agricultural holdings and rural areas were becoming multi-functional rather than single-functional. 


\section{Changes of farm households income}

The primary function of agricultural holdings is production. Central Statistical Office mentions the following tendencies in production:

- holdings totally switch to subsistence farming,

- holdings partially switch to subsistence farming,

- holdings sell their goods mainly to the market.

As a result of capitalist transformation of the system, throughout 1990s and also in the present decade, a holding polarization ${ }^{1}$ process was noted. A very large number of agricultural holdings sells much less to the market and many of them resort to subsistence farming. Only a small proportion of holdings became commercial farms.

According to National Agricultural Census in 2002442.5 thousand individual holdings produced goods for own use and 790.5 thousand for own use mainly. This accounted for $56.7 \%$ of total individual farms. These were holdings from the $0-2$ ha area category. 941 thousand holdings produced goods intended for the market mainly and most (359 thousand) produced agricultural goods worth of PLN 5-15,000 (38.2\% of holdings selling goods intended mainly for the market). These were holdings from the 5-10 ha area category. The larger the area of holdings grew, the more important their production function became (the value of agricultural goods sold increased).

According to L. Klank, only about $15 \%$ of agricultural holdings benefitted from the transformation and more than a half was marginalised to the subsistence farming sector, with agricultural production based income of 2.5-5 thousand annually per one family (Nowicki 2003).

In the period of transformation and integration (the last decade of the $20^{\text {th }}$ century and the first decade of the $21^{\text {st }}$ century) the structure of agricultural holdings changed only slightly. However, two tendencies emerged: polarization of the structure and concentrations of land in the largest holdings and that despite the slow growth rate of their total number. Polarization was a result of rational decisions of farmers: either a "retreat" from agriculture (switching to the social group) or making it larger in order to obtain a larger market share or maintaining the existing one. A progressive process of polarization of family holdings into social and market-oriented holdings was observed.

In the early days of Polish integration with the EU (in 2004) the structure of agricultural holdings was as follows (Józwiak 2006):

- the first "pole" covered social holdings (about $1 \mathrm{~m}$ holdings of size up to $2 \mathrm{ESU}$, including 670 thousand with an area of less than 1 ha, i.e. $36 \%$ of the total number), agriculture production based income in those holdings was very modest and consisted $9-10 \%$ of total family income.

- the second pole covered Polish farms (about 220-230 thousand holdings, i.e. of the total number) with a size of 8 ESU or more, which was indicative of a large production scale and positive reproduction of fixed assets.

In 2007, as many as $68 \%$ (more than $1.6 \mathrm{~m}$ ) of individual holdings had a low economic strength (up to 2 ESU) and 21.8\% (520.9 thousand) were holdings which did not pay the parity fee (2-8 ESU). Holdings which paid the parity fee but provided low return on equity (8-16 ESU) accounted for $6.8 \%$ ( 82 thousand) and the holdings in which there was a parity between own work and profitability (i.e. more than $16 \mathrm{ESU}$ ) accounted for $4 \%$ only. (96.6 thousand of holdings) ${ }^{2}$

\footnotetext{
${ }^{1}$ The term "polarization" is mainly used in agricultural economics to emphasize the polar character of differences between agricultural holdings in terms of size, income, production etc.

2 This category also included holdings with an area of up to 1 ha (parcels to be more precise). Unfortunately, the empirical data available does not allow us to categorize this group as an entity which could be considered
} 
Area polarization of holdings was a slower process than their socio-economic polarization. In rural families in particular, a process of income polarization can be noted. This process can be evidenced by a large scale of peasant poverty (or rural poverty more generally speaking) on the one hand and on the other by the fact that few farmers agricultural producers and apt managers of holdings with a high production potential - have a high income. In 2008, average monthly income of an individual holding per 1 person in a farmer household in the area category of 20.00 ha and more was 2.7 greater compared to the 1.00- 4.999 group. The same was the case with one-person holdings compared to six-person holdings: 3.2 times and 2.2 times respectively.

Polarization of functions of family holdings was caused by the emergence of alternative sources of income. For instance, there is a large share of temporary work and social benefits in the income structure (Zegar 2006). Some proportion of holdings, especially those with large areas of agricultural land and extensive production resources transformed into family enterprises, creating a base for agricultural families. Some proportion of rural population gave up agricultural activity which resulted in an increase in the number of rural families which are not in possession of an agricultural holding. "As a result - as A Sikorska writes - the number of rural non-peasant population constantly increased". In 1988-2005, the percentage share of families with an agricultural holding user decreased from $58.5 \%$ to $43 \%$, whereas in the very same period the percentage share of families without an agricultural holding user increased from $41.5 \%$ to $57 \%$ (Sikorska 2007). The emergence of a large proportion of rural families without a holding in the course of system transformation was more obvious; a large number of this population became economically inactive (with some of them working on a temporary basis or illegally); and emigrated.

An example of the changes in the country and in the rural community are also changes in the structure of individual holdings in terms of the main source of income for holdings. In 2002 , households in which $50 \%$ of income was based on pensions and disability benefits $(30.9 \%)$ were most numerous. Households with temporary work based income came second $(27.1 \%)$ and agriculture-based income $(20.8 \%)$ came third. However, in 2007 households with $50 \%$ of total income based on temporary work (increase by $31.6 \%$ ) were first, households with agriculture based income (increase by $25.3 \%$ ) came second and pension and disability benefit income based household were ranked third (decline by $24.1 \%$ ) (Statistics and characteristics 2002).

\section{Structural changes in individual farms}

In 2002-2007 there was a drop in the total number of farms by $12.1 \%$, it included decrease by $21.1 \%$ for farms with the agricultural land area of up to 1 ha (parcels) and with the agricultural land area of above 1 ha by $7.6 \%$. A drop was also noted in the area of agricultural lands, which were used both in the group of parcels, as well as in the group of farms with the area of above 1 ha of agricultural land (Table 1).

separate from the total group of holdings classified according to their economic strength. 
Table 1. Changes in the number of individual farms in Poland within the period before and after CAP introduction

\begin{tabular}{|c|c|c|c|c|c|c|}
\hline \multirow{3}{*}{$\begin{array}{c}\text { Area of } \\
\text { agricultural } \\
\text { land in ha }\end{array}$} & \multicolumn{6}{|c|}{ Number of farms } \\
\hline & \multicolumn{3}{|c|}{ in absolute numbers } & $\%$ & \multicolumn{2}{|c|}{ structure in $\%$} \\
\hline & 2002 & 2007 & $\begin{array}{l}\text { difference } \\
2007-2002\end{array}$ & $\frac{2007}{2002}$ & 2002 & 2007 \\
\hline Total & $2,928,578$ & $2,575,113$ & $-353,465$ & 87.9 & 100.0 & 100.0 \\
\hline from 0 to 1 ha & 976,852 & 771,050 & $-205,802$ & 78.9 & 33.4 & 29.9 \\
\hline above 1 ha & $1,951,726$ & $1,804,063$ & $-147,663$ & 92.4 & 66.6 & 70.1 \\
\hline in ha & \multicolumn{3}{|c|}{ in absolute numbers } & \multicolumn{3}{|c|}{ farms larger than $1 \mathrm{ha}=100$} \\
\hline $1-2$ & 516,836 & 422,533 & $-94,303$ & 81.8 & 26.5 & 23.4 \\
\hline $2-3$ & 280,996 & 273,675 & $-7,321$ & 97.4 & 14.4 & 15.2 \\
\hline $3-5$ & 348,466 & 340,303 & $-8,163$ & 97.7 & 17.9 & 18.9 \\
\hline $5-10$ & 426,520 & 399,868 & $-26,652$ & 93.8 & 21.9 & 22.2 \\
\hline $10-15$ & 182,505 & 166,435 & $-16,070$ & 91.2 & 9.4 & 9.2 \\
\hline $15-20$ & 83,790 & 77,474 & $-6,316$ & 92.5 & 4.3 & 4.3 \\
\hline $20-30$ & 64,080 & 65,189 & 1,109 & 101.7 & 3.3 & 3.6 \\
\hline $30-50$ & 31,432 & 37,126 & 5,694 & 118.1 & 1.6 & 2.1 \\
\hline $50-100$ & 11,977 & 15,615 & 3,638 & 130.4 & 0.6 & 0.9 \\
\hline 100 and more & 5,124 & 5,846 & 722 & 114.1 & 0.3 & 0.3 \\
\hline
\end{tabular}

Source: Statystyka $i$ charakterystyka gospodarstw rolnych $w 2002 r$. (Statistics and characteristics of agricultural holdings in 2002), CSO, Warsaw 2003, p. 112 and Charakterystyka gospodarstw rolnych $w 2007$ roku (Characteristics of agricultural holdings in 2007), CSO, Warsaw 2008, p. 154.

Analysis of the change in the number of farms (above 1 ha) by size groups showed that in 2002-2007 the number of farms in the size group covering farms from 1 to 20 ha decreased, and it increased in the size group of farms above 20 ha.

The highest rate of decrease was noted in the 1-2 ha group (drop by 18.2\%), the lowest - 3-5 ha group $(2.3 \%)$. In absolute numbers the number of farms decreased the most in the following size groups: 1-2 ha (drop by 94.3 thousand); 5-10 ha (drop by 26.6 thousand) and 10-15 ha (drop by 16.1 thousand).

The highest growth rate was noted in the 50-100 ha group (increase by $30.4 \%$ ). In absolute numbers the number of farms increased the most in the 30-50 ha size group (increase by 5.7 thousand).

In the 2002-2007 period the area of agricultural land belonging to individual farms decreased by a total of $3.0 \%$; the group of farms with the area of agricultural land of up to 1 ha (parcels) noted a drop of $16.6 \%$ and the group of farms above 1 ha - by $7.6 \%$. In the group of holdings with the area of agricultural land amounting to more than 1 ha the decrease rate of for the drop in the area was much slower than for the number of farms, which points to a positive change in the agrarian structure - increase in the average area of farms (Table 2). 
Table 2. Changes in the total area of individual farms in Poland within the period before and after CAP introduction

\begin{tabular}{|c|c|c|c|c|c|c|c|c|}
\hline \multirow{3}{*}{ 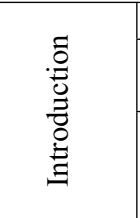 } & \multicolumn{8}{|c|}{ Area of farms } \\
\hline & \multicolumn{3}{|c|}{ in ha } & $\%$ & \multicolumn{2}{|c|}{ structure in $\%$} & \multicolumn{2}{|c|}{$\begin{array}{l}\text { average in the } \\
\text { group, in ha }\end{array}$} \\
\hline & 2002 & 2007 & $\begin{array}{c}\text { difference } \\
2007- \\
2002\end{array}$ & $\frac{2007}{2002}$ & 2002 & 2007 & 2002 & 2007 \\
\hline Total & $14,858,425$ & $14,418,199$ & $-440,226$ & 97.0 & 100.0 & 100.0 & 5.07 & 5.60 \\
\hline $\begin{array}{l}\text { from } 0 \text { to } \\
1 \text { ha }\end{array}$ & 396,482 & 330,824 & $-65,658$ & 83.4 & 2.7 & 2.3 & 0.41 & 0.43 \\
\hline above 1 ha & $14,461,943$ & $14,087,375$ & $-374,568$ & 97.4 & 97.3 & 97.7 & 7.41 & 7.81 \\
\hline \multicolumn{9}{|c|}{ farms larger than 1 ha } \\
\hline \multicolumn{4}{|l|}{ in hectares } & \multicolumn{3}{|c|}{$\begin{array}{c}\text { in } \%(\text { in total above } 1 \mathrm{ha}= \\
100)\end{array}$} & \multicolumn{2}{|c|}{ in hectares } \\
\hline $1-2$ & 725,041 & 613,315 & $-111,726$ & 84.6 & 5.0 & 4.4 & 1.40 & 1.45 \\
\hline $2-3$ & 684,603 & 667,412 & $-17,191$ & 97.5 & 4.7 & 4.7 & 2.44 & 2.44 \\
\hline $3-5$ & $1,353,354$ & $1,322,528$ & $-30,826$ & 97.7 & 9.4 & 9.4 & 3.88 & 3.89 \\
\hline $5-10$ & $3,029,132$ & $2,836,174$ & $-192,958$ & 93.6 & 20.9 & 20.1 & 7.10 & 7.09 \\
\hline $10-15$ & $2,213,745$ & $2,019,873$ & $-193,872$ & 91.2 & 15.3 & 14.3 & 12.13 & 12.14 \\
\hline $15-20$ & $1,437,827$ & $1,333,099$ & $-104,728$ & 92.7 & 9.9 & 9.5 & 17.16 & 17.21 \\
\hline $20-30$ & $1,536,608$ & $1,568,085$ & 31,477 & 102.0 & 10.6 & 11.1 & 23.98 & 24.05 \\
\hline $30-50$ & $1,171,762$ & $1,387,460$ & 215,698 & 118.4 & 8.1 & 9.8 & 37.28 & 37.37 \\
\hline $50-100$ & 799,707 & $1,044,238$ & 244,531 & 130.6 & 5.5 & 7.4 & 66.77 & 66.88 \\
\hline $\begin{array}{l}100 \text { and } \\
\text { more }\end{array}$ & $1,510,163$ & $1,295,191$ & $-214,972$ & 85.8 & 10.4 & 9.2 & 294.72 & 221.57 \\
\hline
\end{tabular}

Source: Statystyka $i$ charakterystyka gospodarstw rolnych $w 2002 r$. (Statistics and characteristics of agricultural holdings in 2002), CSO, Warsaw 2003, p. 112 and Charakterystyka gospodarstw rolnych $w 2007$ roku (Characteristics of agricultural holdings in 2007), CSO, Warsaw 2008, p. 154.

Analysis of the change in the area of agricultural land by size groups of farms (above 1 ha) showed that in the 2002-2007 period the area of agricultural land in the groups of farms from 1 to 20 ha and 100 and more ha decreased and it increased in the groups amounting from 20 to 100 ha. The highest rate of decrease was noted in the 1-2 ha group (drop by $15.4 \%$ ), the lowest in the 3-5 ha group (drop by $2.3 \%$ ). The decrease in the number of hectares of agricultural land was the greatest in the following groups: 100 and more ha (drop by 215.0 thousand ha); 10-15 ha (drop by 193.9 thousand ha) and 5-10 ha (drop by 192.9 thousand ha). The highest growth rate of the agricultural land acreage was noted in the 50-100 ha group (increase by $30.6 \%$ ); this group also noted the highest increase in the agricultural land resources (by $244.5 \mathrm{ha}$ ).

In the 2002-2007 period the average size of agricultural land in an average farm in Poland increased from 5.07 to 5.60, including an increase from 0.41 to 0.43 ha in the group of farms below $1 \mathrm{ha}$, and an increase from 7.41 to 7.81 ha in the group of farms above 1 ha. The average size of agricultural land of a farm also increased within the period in all size groups except for two. A drop was noted in the 5-10 ha size group (from 7.10 to 7.09 ha of agricultural land) and in the size group of the greatest farms (100 and more ha) from 294.72 to 221.57 ha of agricultural land (Statistics and characteristics 2002).

Analysis of the change in the average area of agricultural land in individual size groups of farms points to a tendency for "strengthening" the area of the smallest and larger farms and "weakening" the area of medium-sized and the largest farms. 
In the 2002-2007 there occurred a clear division in the number and structure of farms, which were aggregated according their economic strength expressed in ESU (Poczta, Śledzińska ${ }^{3}$ ). An increase was noted in the number of farms representing two extremes, i.e.:

- farms of very small economic strength (up to 4 ESU);

- farms of moderately small economic strength (only in the subgroup 12-16 ESU) and moderately large economic strength (16-40 ESU); large (40-100 ESU) and very large (100 and more ESU),

and a decreased for farms:

- of small economic strength (4-8 ESU) and moderately small economic strength (only in the subgroup 8-12 ESU).

In the 2002-2007 period the number of farms increased the most in the group of up to 2 ESU (197.3 thousand), which consisted in $90.3 \%$ of the total increase in the number of farms. However, a drop was noted in the number of farms in the group of 4-6 ESU (drop by 9.8 thousand). The highest growth rate in the number of farms was noted in the group of 40$100 \mathrm{ESU}$ (increase by 53.1\%), and the highest rate of decrease in the group of 6-8 ESU (a drop by $9.0 \%$ ). The changes that took place in the structure of farms aggregated according to their economic strength show a clear polarity: an increase in the number of economically weakest and strongest farms, and a drop in the number of small and medium-sized farms (Table 3).

Table 3. Changes in the number and structure of individual farms (together with parcels) carrying out agricultural activity by Economic Size Unit (ESU) in total for Poland within the period before and after CAP introduction

\begin{tabular}{|c|c|c|c|c|c|c|c|}
\hline \multirow[t]{2}{*}{ Specification } & 2002 & 2007 & \multicolumn{2}{|c|}{$\begin{array}{c}\text { Changes in 2002- } \\
2007\end{array}$} & \multicolumn{2}{|c|}{$\begin{array}{c}\text { Structure } \\
\text { in } \%\end{array}$} & \multirow{2}{*}{$\begin{array}{c}\begin{array}{c}\text { Average } \\
\text { area of } \\
\text { agricultural } \\
\text { land in a } \\
\text { farm in ha }\end{array} \\
2007\end{array}$} \\
\hline & in $\mathrm{a}$ & solute numl & & in $\%$ & 2002 & 2007 & \\
\hline Total & $2,168,679$ & $2,387,246$ & 218,567 & 110.1 & 100.0 & 100.0 & 5.95 \\
\hline from 0 to 2 & $1,426,385$ & $1,623,700$ & 197,315 & 113.8 & 65.8 & 68.0 & 1.99 \\
\hline from 2 to 4 & 280,207 & 299,589 & 19,382 & 106.9 & 12.9 & 12.5 & 6.86 \\
\hline from 4 to 6 & 148,259 & 138,433 & $-9,826$ & 93.4 & 6.8 & 5.8 & 9.74 \\
\hline from 6 to 8 & 91,113 & 82,884 & $-8,229$ & 91.0 & 4.2 & 3.5 & 12.20 \\
\hline from 8 to 12 & 100,358 & 95,577 & $-4,801$ & 95.2 & 4.6 & 4.0 & 15.88 \\
\hline from 12 to 16 & 48,528 & 50,504 & 1,976 & 104.1 & 2.2 & 2.1 & 20.04 \\
\hline from 16 to 40 & 62,530 & 79,916 & 17,386 & 127.8 & 2.9 & 3.3 & 30.88 \\
\hline from 40 to 100 & 9,155 & 14,020 & 4,865 & 153.1 & 0.4 & 0.6 & 67.61 \\
\hline from 100 to 250 & 1,646 & 2,123 & 477 & 129.0 & 0.1 & 0.1 & 171.33 \\
\hline 250 and more & 498 & 501 & 3 & 100.6 & 0.0 & 0.0 & 495.76 \\
\hline
\end{tabular}

Source: Statystyka $i$ charakterystyka gospodarstw rolnych $w 2002 r$. (Statistics and characteristics of agricultural holdings in 2002), CSO, Warsaw 2003, pp. 302-303 and Charakterystyka gospodarstw rolnych $w 2007$ roku (Characteristics of agricultural holdings in 2007), CSO, Warsaw 2008, pp. 296-297

\footnotetext{
3 Classification of farms according to their economic strength in ESU; very small (up to 4), small (4-8), moderately small (8-16), moderately large (16-40), large (40-100), very large (100 and more).
} 


\section{Changes of functions of farm households}

Taking into account the lack of continuity as regards publication of data on the number of individual farms by the direction of their production and its scale (concerns production for own or market needs; see Table 1) for the needs of the analysis of the change in the function of farms an "over $50 \%$ indicator was adopted to determine the share of income in the total income of a household from the following sources: agricultural activity; agricultural activity and paid employment; paid employment; paid employment and agricultural activity; nonagricultural activity; retirement and disability pensions; non-earned sources" (Table 19, Statistics and characteristics 2002; Table 83, Characteristics 2007).

It was assumed that the increase in 2002-2007 period in the number of farms, in which over $50 \%$ of income was obtained from "agricultural activity" points to an increase in the group of farms that fulfil functions within the scope of agricultural production. Increase in the number of farms in which over $50 \%$ of income was obtained from agricultural activity and paid employment points to a growth in the group of farms that fulfil mixed functions. Increase in the number of farms in which over $50 \%$ of income was obtained from non-agricultural activity, which covers: paid employment and non-agricultural activity shows an increase in the group of farms that fulfil non-agricultural functions (including: subsistence, recreational functions). Increase in the number of farms in which over $50 \%$ of income was obtained from retirement and disability pensions and non-earned sources of income points to an increase in the group of farms that fulfil social functions (including: subsistence, recreational functions).

An increase in the significance of the production function of a farm points to farms development tendency towards their "agricultural" function (single-employment), increase in the significance of the mixed function - towards multi-functionality (multiple-employment) and of the non-agricultural function - towards subsistence and recreational functions of farms (Table 4; 5).

Table 4. Changes in the source of income of individual farms according to the major source of income of a household before and after CAP introduction

\begin{tabular}{|c|c|c|c|c|c|c|c|c|}
\hline \multirow{4}{*}{$\begin{array}{l}\text { Farms in } \\
\text { which over } \\
50 \% \text { of } \\
\text { income was } \\
\text { obtained } \\
\text { from: }\end{array}$} & \multicolumn{6}{|c|}{ Poland } & \multirow{3}{*}{\multicolumn{2}{|c|}{$\begin{array}{c}\text { Share of } \\
\text { Mazowieckie } \\
\text { Voivodeship } \\
\text { Poland in general } \\
=100^{*}\end{array}$}} \\
\hline & \multicolumn{4}{|c|}{ Individual farms } & \multirow{2}{*}{\multicolumn{2}{|c|}{$\begin{array}{l}\text { Changes in } \\
2002-2007\end{array}$}} & & \\
\hline & \multicolumn{2}{|c|}{ number } & \multicolumn{2}{|c|}{ Total $=100(\%)$} & & & & \\
\hline & 2002 & 2007 & 2002 & 2007 & $\begin{array}{c}\text { in } \\
\text { numbers }\end{array}$ & in $\%$ & 2002 & 2007 \\
\hline 1 & 2 & 3 & 4 & 5 & 6 & 7 & 8 & 9 \\
\hline $\begin{array}{l}\text { agricultural } \\
\text { activity }\end{array}$ & 609,572 & 602,878 & 20.8 & 25.3 & $-6,694$ & 98.9 & $17.1(1)$ & $18.3(1)$ \\
\hline $\begin{array}{l}\text { agricultural } \\
\text { activity and } \\
\text { paid } \\
\text { employment }\end{array}$ & 25,326 & 29,151 & 0.9 & 1.2 & 3,825 & 115.1 & $16.1(1)$ & $11.8(3)$ \\
\hline $\begin{array}{l}\text { paid } \\
\text { employment }\end{array}$ & 793628 & 755298 & 27.1 & 31.6 & -38330 & 95.2 & $12.9(1)$ & $11.8(3)$ \\
\hline $\begin{array}{l}\text { paid } \\
\text { employment } \\
\text { and } \\
\text { agricultural } \\
\text { activity }\end{array}$ & 79,878 & 101,926 & 2.7 & 4.3 & 22,048 & 127.6 & $10.3(4)$ & $9.4(3)$ \\
\hline
\end{tabular}




\begin{tabular}{|l|c|c|c|c|c|c|c|c|}
\hline \multicolumn{1}{|c|}{$\mathbf{1}$} & $\mathbf{2}$ & $\mathbf{3}$ & $\mathbf{4}$ & $\mathbf{5}$ & $\mathbf{6}$ & $\mathbf{7}$ & $\mathbf{8}$ & $\mathbf{9}$ \\
\hline $\begin{array}{l}\text { non- } \\
\text { agricultural } \\
\text { activity }\end{array}$ & 168,369 & 117,576 & 5.8 & 4.9 & $-50,793$ & 69.8 & $13.2(1)$ & $15.5(1)$ \\
\hline $\begin{array}{l}\text { retirement } \\
\text { and } \\
\text { disability } \\
\text { pensions }\end{array}$ & 905,996 & 574,368 & 30.9 & 24.1 & $-331,628$ & 63.4 & $9.6(5)$ & $9.3(5)$ \\
\hline $\begin{array}{l}\text { non-earned } \\
\text { sources of } \\
\text { income }\end{array}$ & 151,875 & 26,302 & 5.2 & 1.1 & $-125,573$ & 17.3 & $12.7(1)$ & $12.1(2)$ \\
\hline Other farms & 193,315 & 179,746 & 6.6 & 7.5 & $-13,569$ & 93.0 & $11.3(3)$ & $12.0(3)$ \\
\hline
\end{tabular}

* Total number of farms in Poland in a given group of farms, in which over $50 \%$ of income was obtained from a given activity. The figure in brackets stands for the rank in the country.

Source: Statystyka i charakterystyka gospodarstw rolnych $w 2002 r$. (Statistics and characteristics of agricultural holdings in 2002), CSO, Warsaw 2003, p. 299; Charakterystyka gospodarstw rolnych $w 2007$ roku (Characteristics of agricultural holdings in 2007), CSO, Warsaw 2008, p. 463.

After Polish integration with the EU (2002-2007 period) positive changes were noted in the structure of farms by the predominant source of income, which were manifested, primarily, in the increase in the share of farms that live on paid employment and a drop in farms living on social and non-earned sources of income. Increase in the share of farms in which over $50 \%$ of income was obtained from agricultural activity can point to a growth in the production and agricultural function of farms. Undoubtedly, this partly results from the contribution of the EU financial resources directed to farms under different forms (direct payments or subsidies for restructurisation and modernisation of farms, for development of semi-subsistence farms or for young farmers), but not all farms that received payments increased production. The first group of farms owns their better financial results from agriculture only to subsidies.

Second group of farms that noted an increase of their share in the structure in the 2002-2007 period covers the group in which over 50\% of income was obtained from paid employment. This suggests that for a family employed, above all, in non-agricultural employment the farm fulfils a subsistence function, recreational function or it acts as the place of residence (for example, some part of land may be leased). However, according to J. St. Zegar, the non-farmers also cover a group of economically viable farms, which "do not have (...) a significant position in the structure of individual farms as their share in the general number of farms amounts only to 1.3\%" (approx. 31 thousand of farms) (Zegar 2009 ${ }^{4}$ ).

Third group of farms that noted an increase of their share in the structure in the 20022007 period covers the group in which over $50 \%$ of income was obtained from two sources of income: paid employment and agricultural activity, and the greater growth rate was noted for the sub-group "paid employment and agricultural activity" than for "agricultural activity and paid employment" sub-group. The increasing tendency in this group of farms can have a positive impact on the improvement of infrastructural equipment and marinating vitality of rural areas.

\footnotetext{
4 "The term "non-farmers" should be understood as households in which the predominating part of income derives from non-agricultural sources." (...) Agricultural holdings used by households consisting of farm users that obtain their basic (major) income from non-agricultural sources (paid employment, retirement and disability pensions, etc.) shall be termed jointly as households used by non-farmers for the purposes of this article." "Under the conditions of Polish agriculture the term economically viable farms, in general, refers to these farms for which the economic size amounts to at least 8 ESU."
} 
Table 5. Regional differentiation of changes in the function of individual farms according to the source of income in households

\begin{tabular}{|c|c|c|c|c|c|c|c|c|c|c|}
\hline \multirow{7}{*}{ 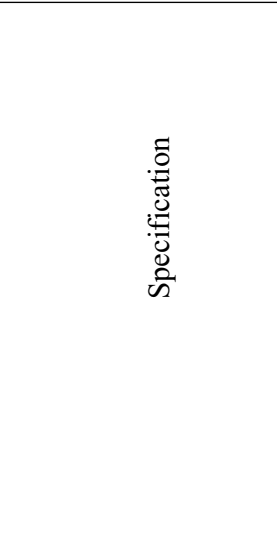 } & \multicolumn{8}{|c|}{$\begin{array}{r}\text { Individual farms, in which over } 50 \% \text { of income was } \\
\text { obtained from: }\end{array}$} & \multirow{5}{*}{\multicolumn{2}{|c|}{ 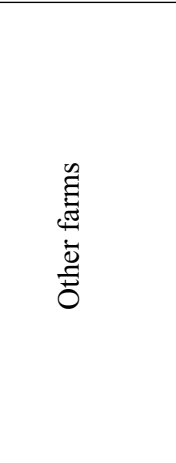 }} \\
\hline & \multicolumn{2}{|c|}{$\begin{array}{l}\text { agricultural } \\
\text { activity }\end{array}$} & \multicolumn{2}{|c|}{$\begin{array}{l}\text { agricultural } \\
\text { and non- } \\
\text { agricultural } \\
\text { activity }\end{array}$} & \multicolumn{2}{|c|}{$\begin{array}{c}\text { paid } \\
\text { employment } \\
\text { and non- } \\
\text { agricultural } \\
\text { activity }\end{array}$} & \multicolumn{2}{|c|}{$\begin{array}{l}\text { retirement } \\
\text { and } \\
\text { disability } \\
\text { pensions and } \\
\text { non-earned } \\
\text { sources of } \\
\text { income } \\
\end{array}$} & & \\
\hline & \multicolumn{8}{|c|}{ Functions of individual farms* } & & \\
\hline & \multirow{2}{*}{\multicolumn{2}{|c|}{$\begin{array}{l}\text { agricultural } \\
\text { production }\end{array}$}} & \multirow{2}{*}{\multicolumn{2}{|c|}{ mixed }} & $\begin{array}{r}\text { no } \\
\text { agricu }\end{array}$ & $\begin{array}{ll}n- \\
\text { ltural }\end{array}$ & \multirow{2}{*}{\multicolumn{2}{|c|}{ recreational }} & & \\
\hline & & & & & \multicolumn{2}{|c|}{ subsistence, recreational } & & & & \\
\hline & 2002 & 2007 & 2002 & 2007 & 2002 & 2007 & 2002 & 2007 & 2002 & 2007 \\
\hline & \multicolumn{10}{|c|}{ Poland in general $=100$} \\
\hline \multirow[t]{2}{*}{ Poland } & 20.8 & 25.3 & 3.6 & 5.5 & 32.9 & 36.6 & 36.1 & 25.2 & 6.6 & 7.5 \\
\hline & \multicolumn{10}{|c|}{ Voivodeships in general $=100$} \\
\hline Dolnośląskie & 17.6 & 18.8 & 2.5 & 3.5 & 35.9 & 44.3 & 38.1 & 26.8 & 5.9 & 6.5 \\
\hline Kujawsko-Pomorskie & 39.8 & 42.9 & 2.7 & 2.9 & 26.1 & 29.4 & 25.8 & 18.7 & 5.7 & 6.1 \\
\hline Lubelskie & 24.2 & 27.8 & 4.0 & 1.8 & 28.3 & 32.2 & 36.9 & 25.9 & 6.6 & 8.9 \\
\hline Lubuskie & 12.2 & 15.6 & 2.4 & 3.7 & 35.4 & 40.4 & 44.1 & 35.0 & 5.9 & 5.3 \\
\hline Łódzkie & 27.3 & 28.7 & 4.4 & 6.3 & 32.1 & 34.9 & 29.4 & 21.2 & 6.7 & 8.9 \\
\hline Małopolskie & 10.9 & 12.5 & 4.4 & 8.0 & 36.5 & 43.6 & 40.2 & 27.2 & 8.0 & 8.8 \\
\hline Mazowieckie & 28.2 & 35.7 & 3.3 & 4.2 & 33.7 & 34.8 & 28.8 & 18.3 & 5.9 & 7.0 \\
\hline Opolskie & 19.2 & 19.3 & 3.2 & 4.7 & 35.9 & 43.0 & 35.7 & 27.3 & 6.0 & 5.8 \\
\hline Podkarpackie & 6.9 & 7.5 & 5.2 & 8.9 & 34.7 & 40.6 & 45.4 & 35.6 & 7.8 & 7.5 \\
\hline Podlaskie & 38.6 & 43.5 & 3.0 & 3.1 & 23.8 & 29.2 & 29.0 & 17.8 & 5.6 & 6.3 \\
\hline Pomorskie & 27.1 & 33.7 & 2.5 & 4.9 & 32.5 & 35.4 & 31.9 & 18.0 & 6.0 & 8.1 \\
\hline Śląskie & 6.3 & 8.0 & 1.9 & 3.9 & 39.8 & 42.7 & 45.7 & 39.6 & 6.2 & 5.7 \\
\hline Świętokrzyskie & 19.1 & 30.8 & 4.1 & 6.7 & 28.9 & 30.7 & 41.0 & 22.9 & 7.0 & 9.0 \\
\hline $\begin{array}{l}\text { Warmińsko- } \\
\text { Mazurskie }\end{array}$ & 30.0 & 37.5 & 1.8 & 3.0 & 27.5 & 31.3 & 35.4 & 23.0 & 5.3 & 5.1 \\
\hline Wielkopolskie & 33.8 & 38.5 & 4.3 & 4.4 & 30.7 & 32.3 & 24.5 & 17.3 & 6.7 & 7.5 \\
\hline Zachodniopomorskie & 17.7 & 25.0 & 2.0 & 5.1 & 35.5 & 38.3 & 39.1 & 24.2 & 5.7 & 7.4 \\
\hline
\end{tabular}

* Functions of individual farms: Agricultural (production) - households, in which over $50 \%$ of total income was obtained from agricultural activity; Mixed - over 50\% of income was obtained from agricultural activity and paid employment; Non-agricultural (non-production, subsistence, recreational) - over $50 \%$ of income was obtained from paid employment and non-agricultural activity; Social (non-production, subsistence, recreational) - over $50 \%$ of income was obtained from retirement and disability pensions and non-earned sources of income.

Source: Author's own elaboration on the basis of: Statystyka i charakterystyka gospodarstw rolnych $w 2002$ r. (Statistics and characteristics of agricultural holdings in 2002), CSO, Warsaw 2003, p. 299; Charakterystyka gospodarstw rolnych w 2007 roku (Characteristics of agricultural holdings in 2007), CSO, Warsaw 2008, p. 463.

Analysis of the change in the structure of farms according to the predominant source of income points to an increase in their production and dual-employment functions and a drop in social function. This confirms the tendency of farms to polarization; on the one hand, towards single-functionality (commercialization), on the other, towards multiple-employment. In a multiple-employment farm the agricultural holding constitutes not only an additional source of income (financial or in the form of subsistence), but it also fulfils a significant 
environmental and recreational functions and it maintains vitality of rural areas.

Below is presented the regional differentiation of changes in the function of individual farms (Chmielewska 2008, Chmielewska 2010).

In 2002 the most "agricultural" Pomorskie, Podlaskie, Wielkopolskie and Warmińsko-Mazurskie. In 2007 this group was increased to seven voivodeships (by Mazowieckie, Pomorskie and Świętokrzyskie). The group of voivodeships with a large acreage of an average farm was joined by the mediumsized farms that can provide for an improvement in the efficiency of farming.

In 2002-2007 also the group of voivodeships with the highest (according to the scale adopted for this ranking ${ }^{6}$ ) share of farms fulfilling "mixed" functions noted an increase from nine to fourteen, as well as the group of "non-agricultural" farms (according to the scale adopted for this ranking ${ }^{7}$ ) - from eleven to fourteen voivodeships. However, the group of voivodeships with the highest (according to the scale adopted for this ranking $^{8}$ ) share of individual farms fulfilling "social" functions noted a decrease from eleven to three voivodeships. This confirms the thesis on improvement of the economic and social condition of farms related to agriculture in rural areas after Polish integration with the EU.

Specialized dairy farms (Podlaskie Voivodeship) constitute a good example of a change in the function of a farm. In Podlaskie Voivodeship the share of farms in which over $50 \%$ of the total income was obtained from agricultural activity increased from $38.6 \%$ in 2002 to $45.5 \%$ in 2007 , and in the raking of voivodeships by the agricultural function of farms it noted an increase from the second to the first rank in the country.

\section{Summary}

- changes in the function of farms and their regional differentiation follow from the political transformation of our country (at the beginning of 1990), Polish integration with the European Union (EU) and the fact that Polish agriculture was covered with the Common Agricultural Policy (CAP) (since 2004).. This transformation was manifested, above all, in the division of Polish farms into two groups: agricultural and commercial farms, as well as subsistence, social and recreational farms.

- positive changes were noted in the structure of farms by the predominant source of income, which were manifested primarily in the increase in the share of farms that live on paid employment and a drop in farms living on social and non-earned sources of income.

- the group of the most agricultural voivodeships taking account their over $50 \%$ share of income deriving from agricultural activity in the total income of the household cover the following voivodeships: Podlaskie, Kujawsko-Pomorskie, Wielkopolskie, WarmińskoMazurskie, Mazowieckie, Pomorskie and Świętokrzyskie. Among these voivodeships the share of farms with the predominance of agricultural income was shaped at the level from 43.5\% (Podlaskie voivodeships) to 30.8\% (Świętokrzyskie Voivodeship).

\footnotetext{
${ }^{5}$ The following scale was adopted: the voivodeships with the highest share of farms fulfilling the "agricultural" function cover these voivodeships in which $30.0 \%$ and more farms showed that over $50 \%$ of their total income was obtained from agricultural activity.

${ }^{6}$ The following scale was adopted: the voivodeships with the highest share of farms fulfilling the "mixed" function cover these voivodeships in which $3.0 \%$ and more farms showed that over $50 \%$ of their total income was obtained from agricultural and non-agricultural activity.

${ }^{7}$ The following scale was adopted: the voivodeships with the highest share of farms fulfilling the "non-agricultural" function cover these voivodeships in which $30.0 \%$ and more farms showed that over $50 \%$ of their total income was obtained from paid employment and non-agricultural activity.

8 The following scale was adopted: the voivodeships with the highest share of farms fulfilling the "social" function cover these voivodeships in which $30.0 \%$ and more farms showed that over $50 \%$ of their total income was obtained from retirement and disability pensions and non-earned sources of income.
} 
- all voivodeships note a large share of individual farms, in which over $50 \%$ of the total income consists of income from paid employment and non-agricultural activity. Among a total of 16 voivodeships in the country, for 14 this share is shaped at the level from $44.3 \%$ in Dolnośląskie Voivodeship to $30.7 \%$ in the Świętokrzyskie Voivodeship. Only in two voivodeships this indicator was lower than $30 \%$, but it was still high (in Kujawsko-Pomorskie Voivodeship - 29.4\%; and in Podlaskie Voivodeship - 29.2\%),

- the direction of changes in the function of farms can be either a determinant of development or stagnation on rural areas,

- there was also a significant regional diversification as regards the activity of farms within the scope of obtaining EU resources, both in the form of subsidies and other forms of financial support.

\section{References}

1. Charakterystyka gospodarstw rolnych $w 2007$ roku (Characteristics of agricultural holdings in 2007), CSO, Warsaw 2008.

2. Chmielewska B., 2010: Sources of Income as an Indicator of Changes in the Farm Functions, Economics \& Sociology Centre of Sociological Research Foundation of International Studies, Vol 3, No 1 Kyiv-Ternopil,2010.

3. Chmielewska B., 2008: Polaryzacja gospodarstw rolnych pod wplywem WPR $w$ Polsce na przykladzie województwa mazowieckiego (Polarization of Polish farms under the impact of the CAP in Poland on the example of the Mazowieckie Voivodeship). Chapter I [in:] Raport o wptywie wspólnej Polityki Rolnej na tendencje polaryzacji gospodarstw rolnych $w$ ramach poszczególnych regionów kraju (Report concerning the impact of the Common Agricultural Policy on the polarization trends of farms within the framework of individual regions of the country). Part two. Collective work under the scientific guidance of W. Michna. Multi-annual Programme 2005-2009, No. 94 IAFE- NRI. Warsaw.

4. Józwiak W., 2006: Obecne przemiany polskiego rolnictwa i perspektywa 2007-2013 (Current transformation in the Polish agriculture and perspectives for 2007-2013), Presentation delivered during a conference entitled: "Polska wieś od nowa - szanse obszarów wiejskich $w$ perspektywie 2007-2013" (Polish rural areas from the beginning - opportunities of rural areas for the 2007-2013 perspective), Office of the Committee for European Integration, Ministry of Agriculture and Rural Development, Warsaw 07.12.2006.

5. Nowicki F., 2003: Kwestia agrarna w Polsce (Agrarian issues in Poland). Part II. Typescript, http://lbc_1917_3.w.interia.pl.

6. Poczta W., Śledzińska J., 2007: Wyniki produkcyjno-ekonomiczne i finansowe indywidualnych gospodarstw rolnych wedlug ich wielkości ekonomicznej (na przykładzie regionu FADN Wielkopolska i Ślask) [Production, economic and financial results of individual farms according to their economic size (on the example of Greater Poland and Silesia FADN regions)]. Annals of the Polish Association of Agricultural and Agribusiness Economists, Kraków 2007

7. Statistical Yearbook of Agriculture and Rural Areas 2008. CSO, Warsaw 2008.

8. Sikorska A., 2007: Przeobrażenia w strukturze spoleczno-ekonomicznej wsi a proces właczania się Polski do wspólnej polityki rolnej Unii Europejskiej. Synteza (Transformation of the socio-economic structure of rural areas and the process of Polish integration into the Common Agricultural Policy of the European Union. Synthesis), Research work No. 1 H02C 035 28, IAFE-NRI, Warsaw. 
9. Statystyka $i$ charakterystyka gospodarstw rolnych $w 2002$ r. (Statistics and characteristics of agricultural holdings in 2002), CSO, Warsaw 2003.

10. Tomczak F., 2005: Gospodarka rodzinna w rolnictwie. Uwarunkowania i mechanizmy rozwoju (Family farming in agriculture. Development conditions and mechanisms). Institute of Rural and Agricultural Development National Research Institute, Warsaw.

11. Zegar J. St., 2006: Źródla utrzymania rodzin powiązanych z rolnictwem (Sources of income of families connected with agriculture). Research and Monograph No. 133, IAFE-NRI, Warsaw.

12. Zegar J. St., 2009: Ekonomicznie żywotne gospodarstwa rolne użytkowane przez nierolników (Economically viable farms operated by non-farmers). Statistical News No/7/July 2009, CSO, Polish Statistical Association, Warsaw. 